\title{
Harmonization of Law to the Protection of Children's Right Caused by Divorce in Indonesia
}

\author{
Arief Syahrul Alam ${ }^{1} \quad$ Andy Usmina Wijaya ${ }^{2}$ Fifin Dwi Purwaningtyas ${ }^{3}$
}

\begin{abstract}
Law development can be built from awareness as part of international society. Particularly, those relating to basic rights as in children's right protection that applied universally. This is unavoidable that Indonesia has a strong commitment to the legal protection of children's right. by ratifying The Convention of the Right of The Child according to the Constitution of the Republic of Indonesia Number 10 of 2012 about the Child Convention. For that reason, Indonesia should do harmonization to the relating laws of children's rights protection, especially to the children's right caused by divorce of their parents. However, harmonization or unification to international law ideally should pay attention to the values of justice that grow and develop as the nation values, or 'volkgeist' of Indonesia people that sourced from Pancasila.
\end{abstract}

DOI: $10.7176 / J L P G / 93-05$

Publication date: January $31^{\text {st }} 2020$

\section{Introduction}

A marriage is physical and spiritual bond between a man and a woman as husband and wife with purpose to form a happy and eternal family based on the Belief in the One and Only God (Ketuhanan Yang maha Esa). Marriage is a very sacred relationship as in written in UU No. 1 of 1974 about Marriages (UU of Marriages), because it not only involves the outward aspects but also relates to the inner aspects between husband and wife. Besides, the perspective of marriage law based on the UU is not only common relation or civil contract, although each has own right and duty mutually between husband and wife also children that is born. The relationship of husband and wife based on the UU of Marriages also not only gives the responsibility mutually between marriage couple but also has responsibility vertically to the God.

However, in the journey of marriage often occurs disputes which end to a divorce. The result of marital breakdown could happen a divorce, in which it not only impacts to husband and wife but also the children. In this perspective, what that should be noted that in marriage rises right and obligation, in divorce also rises legal consequent to husband and wife also children that was born from that marriage.

Divorce, whatever the reason is a disaster for children because they will no longer be able to enjoy the love of the both parents which should be very important for their mental growth, and usually the breakdown of household results the neglect of childcare. For children, their parents' divorce is thing that will jiggle their lives and will have negative impact to their growth and development, so children are the ones who suffer from their parents' divorce. ${ }^{4}$

The most common problem is that a divorced husband or wife often neglect their obligation, especially the obligation to provide a living after divorce. Normatively, provision of income caused by marital breakdown has been arranged in chapter 41 of Marriage UU, which determines:

a. Whether mother or father remains obliged to care and educate their children, solely based on the interest of children; when there are disputes over the children mastery, the Court gives the decision;

b. Father is responsible for all the care and education that the child needs; when in fact the father cannot fulfil those obligations, the Court can decide mother to take those responsibility;

c. The court may require the ex-husband to provide living expenses and/or decide an obligation to ex-wife.

In fact, the obligation of father to his children is often neglected. Even though in the regulation, the burden of the cost liability to children's living, the Court can decide to take responsibility of it.

On the other hand, there is a regulation about the child's right to be fulfilled the living expenses by his/her parents, although the parents have separated legally or divorced. That regulation is determined in Chapter 14 of UU No. 35 of 2014 about The Change of Law No. 23 of 2002 about Children Protection that determine:

1. Every child has the right to be cared by his/her own parents unless there is a reason and/or legal rule that lawfully indicates the divorce is for the sake of the child and the last consideration.

2. In the divorce case, which is meant on verse (1), child has right:

a. Meeting directly and having personal contact regularly with both parents;

b. Obtaining care, living, education, and protection for the process of growth and development of both parents according to their abilities, talents, and interests;

\footnotetext{
${ }^{1}$ Faculty of Law, Wijaya Putra University, Surabaya, Indonesia.

${ }^{2}$ Faculty of Law, Wijaya Putra University, Surabaya, Indonesia.

${ }^{3}$ Faculty of Psichology, Wijaya Putra University, Surabaya, Indonesia.

${ }^{4}$ Satria Effendi, Problem of the Law of Contemporary Islamic Family, Kencana, Jakarta, 2004, p.197.
} 
c. Obtaining living expenses of both parents;

d. Obtaining other children's right.

From that statement, it can be seen that the regulation to children's rights protection is still lacking and does not yet provide a protecting nuance to children comprehensively especially when it is related to the implementation of marriage decision in terms of children's right. This is caused by the several factors including legal arrangements regarding the children's rights protection after marriage which have not been regulated in a comprehensive frame of legislation and the second is the dualism of regulations which are compiled at different times and socio-politic condition.

From the description above, there is a problem that is quite interesting to be further analyzed is how the arrangement implementation caused by divorce as an effort to provide legal protection for children's growth who were born from those marriages.

\section{Discussion}

In various modern and advanced countries, the law diversity is still found in the law development. That condition is known with legal pluralism. Lawrence M.Friedman defines legal pluralism as "... the existence of different legal systems or legal culture in a single political community"1... a condition that occurs in any social area, where all community activities in that area are governed by more than one orderly law". ${ }^{2}$ from two definitions given, it can be interpreted that legal pluralism is the enactment of two or more legal systems in a society within a country.

As in Indonesia, until now, there are legal diversity that is enforced by the countries to their people. Even to particular legal system, there are laws made by country (state law) and there are lawyers that are enacted and applied corporately by the people themselves, such as customary law, religious law, etc. In fact, as long as customary law is still capable to be foundation in solving problems, then that group of people will not use nor choose state law. State law is only the people's last choice when customary law is no longer capable in providing problem settlement that is faced by people. ${ }^{3}$

Philosophically, law diversity that enforced in a country is intended to provide freedom to the people to choose and implement the law they want. ${ }^{4}$ While sociologically, legal pluralism is still recognized and implemented in people's lives. Where there are people who implement state law and at the same time also carry out customary law and religious law. However, those three systems, exist corporately one among another (coexistent). ${ }^{5}$

In juridical sense, legal pluralism is started when the Indonesian Constitutional Law and Administrative Procedure applies, which is subsequently affirmed based on the provision Transition Rules Chapter II of UUD 1945 that state: “... all officials and regulations are fixed as long as they are new according to UUD 1945". From that provision, The Founding Father provides message to the officials and government of Indonesia to end the enactment of various ex-colonial's laws and regulations and replace them with new self-made's laws and regulations. ${ }^{6}$

One of the legislation that still uses the era of the Dutch East Indies government is relating to marriage law especially one of marriage case implementation. Although normatively, marriage law in Indonesia is regulated based in Marriage UU, however when occurs divorce in marriage case implementation, it still uses Herzein Indlandsch Reglement (HIR). From that two legislations, it is clear that they have differences whether from the substation, basic form, and the culture that contained in the process of it formation.

This is caused by the Constitution of Religious Court in Indonesia which is not regulated procedural law relating to the execution of Religious Court decision. Chapter 54 of UU No. 7 of 1989 of the Religious Court which was last modified according to UU No. 50 of 2009 of the Second Change Over UU No. 7 of 1989 regarding the Religious Court that state "... that procedural law that applied to the court within the Religious Court is Civil Procedural Law which is applied in the General Justice environment, except one which is specifically regulated in this Constitution.

Some chapters regulate the implementation of the court decision in chapter is determined in 196 of HIR which states:

If the defeated party is unwilling or negligent to fulfill the contents of the decision peacefully, then the winning party submits a request, both verbally and by letter, to the head of the district court mentioned in the

\footnotetext{
${ }^{1}$ Lawrence M. Friedman, A Legal Sistem A Social Science Perspective translated by M. Khozim, Nusa Media, Bandung, 2009 , p.257.

2 Jhon Griffiths, Understanding Law, A Conceptual description in Pluralism law: An Interdisciplinary Approach, translated by Andri Akbar et al. Huma, Jakarta, 2005, p.69-71

${ }^{3}$ Ibid, p. 180

${ }^{4}$ Salim, Erlies Septiana Nurbadi, The Application of Legal Theory in Research of Thesis and Dissertation, 5th Publication, Rajawali Press, Depok, 2017, p.98

${ }^{5}$ Ibid, p.101.

${ }^{6}$ Basuki Rekso, Wibowo, The Reformation of Indonesi Legal Based on Pancasila, Scientific Oration of Bachelor Graduation Program, Wijaya Putra University, 9 November, 2019. p.2
} 
first paragraph of verse 195. To implement this decision, the Official Head calls the defeated party and warns to fulfill that decision within the tempo determine by the Head, 8 days at the most.

The request can be submitted either to the Head of the District Court or the Religious Court depending on what law is used in the divorce process. If the divorce is filed in Islam in the Religious Court, the request for the implementation of the decision must also be submitted to the Religious Court and vice versa must be submitted in the District Court. Based in that request, the Court Head calls and warns ex-husband to fulfill the living based on Divorce Decision, no later than 8 days, after called of warned. When husband after being called and warned, still does not fulfill his obligation, wife could request confiscation of husband's property according to chapter 197 of HIR paragraph 1 that determines:

If the specified tempo is passed, and the defeated party has not fulfilled that decision yet, or if properly called, do not come, then the Head will give command by letter, to confiscate items that are not fixed, and if there is none or not enough, the one who defeated will substitute the amount of money in that decision until it is enough, plus all the cost to carry out the decision.

From this, it can be seen that there is a dualism of arrangements relating to the obligation to provide for living with the implementation of providing a living. From both arrangements, there is difference between two principal, the one is the religious court which is law product after the independence, the other is the implementation of the religious court is colonial product. The second arrangements between those two arrangements, there is a difference in the spirit of its formation where UU of the Religious Court is mostly affected by Islam Law, but HIR is purely intended for non-Islamic. Particularly when we pay close attention to the chapters in the HIR relating to the implementation of court decisions and foreclosures which is started from civil relations and more nuanced materiality in the confiscation process. This is contrast with the essence of marriage and divorce that is regulated in UU of Marriage and the Religious Court that full of religious, spiritual and morality.

Besides, UU of Marriage and the implementation of divorce decision in Indonesia, has not comprehensively accommodated the substance related to legal protection of born-children during marriages. Although Indonesia government has been ratified by The Convention of The Right of The Child according to UU of Indonesia Republic No 10 of 2012 regarding Children Convention.

If we look at the concept of children protection also children's right in that convention which includes survival right, health standard, right to grow and develop, even the recognition of children's political rights that so far has not been a priority of Indonesia legislation. Children's rights in The Convention of The Right of The Child are grouped in 4 categories:

a. Right to continue living (survival right), is children's rights include right to preserve and sustain life (the right of life) and right to obtain highest health standards and good treatment (the right to the highest standard of health and medical care attainable);

b. Protection right is rights includes protection of discrimination, violence, and neglect for children who do not have family or children refugee;

c. Right to grow and develop (development rights), is rights include educational forms (formal and nonformal) and right to achieve an adequate standard of living for the child's physical, mental, moral, and social development;

d. Right to participate (participation rights), is rights include the rights of the child to express opinion in all matters affecting the child (the rights of a child express her/his views in all affecting that child).

From the grouping that were formulated by The Convention on The Right of The Child, it can be used as a reference for the legislation draft of children's rights in Indonesia including those whose parents are divorced. As it is known that in essence, the protection of children's rights is part of the legal protection that starts from the basic rights of freedom, survival, and right to be protected. Although the concept of legal protection is sourced from the concepts of Rechstaat or Rule of The Law that are known in Western countries. However, those thoughts in modern countries based on the law, the basic rights of citizens can be followed from the basis of the state or the country's constitution. That legislation effort is a form of legal protection which is divided in 2 by Philipus M. Hadjon "... preventive legal protection is aimed to prevent disputes on the other hand repressive legal protection is aimed to resolve disputes". ${ }^{2}$

Efforts that can be done after ratifying is harmonization and unification to applicable law based on international convention. The concept of law harmonization basically its meaning is often equated with legal unification that is uniformity of the regulatory substance of the existing legal system. That uniformity includes the integration of law system which previously exist. ${ }^{3}$ Unification has meaning as an acceptance of an agreed set of rules, standards or guidelines for the implementation of international conventions. While harmonization means a process in order to avoid conflict and produce a balance. Harmonization is more directed at changing

\footnotetext{
${ }^{1}$ Darwan Prinst, Indonesia Child Law, Citra Aditya Bakti, Bandung, 1997, p.103.

${ }^{2}$ Philipus M. Hadjon, Legal Protection for Indonesian People, PT. Bina Ilmu, Surabaya, 1987, p.2

${ }^{3}$ Huala Adolf, International Trade Law, Raja Grafindo Persada, Jakarta, 2005, p.32
} 
existing rules so that harmony arises. The purpose of law harmonization is trying to find uniformity or meeting point of legal principles that are fundamental to the existing legal system. ${ }^{1}$ Law harmonization is also meant as an effort to adjust:

a. The existing of conflicting things, oddities;

b.Aligning conflicting things proportionally to form a system;

c. A process or an effort to realize harmony, compatibility, and balance;

d.Cooperation between various factors is such that these factors produce a sublime unity. ${ }^{2}$

However, the steps of harmonization or unification as the consequence of ratification of The Convention on The Right of The Child, ideally should pay attention to the values of justice that grow and develop as the values of the nation. The thoughts of justice theory, especially in legal studies so far have been strongly influenced by the tradition of Western philosophical thought which may not be accepted or applied in Indonesia. Thoughts about the philosophy of justice that have chained both the pattern of thought and the study tradition of the law philosophy about justice, which are often taken for granted without being criticized in advance.

In the development of theory nowadays, it has developed a justice theory which bases on Volkgeist that is Pancasila soul nation. The originator of this theory was named the theory as dignified justice. Dignified justice theory has the dimension of transformation of thought and its dependence on the dominance of western philosophical ideas which dominate thoughts and studies of legal justice. Dignified justice theory based on modern legal thought according to Volkgeist Indonesia, which originated from Pancasila.

This thought is based on the understanding that Pancasila as the Indonesian National Volkgeist, which was agreed as a first agreement, as the source of all sources of agreement, the source of all sources of law, as well as the philosophy of the nation. The Theory of Dignified Justice views that the Volkgeist or Pancasila was an inspiration of enlightenment that was dug out of the soul of the nation. ${ }^{3}$

The foundation of the theory of dignified justice starts from two basic philosophies in Pancasila, especially about social justice and fair and civilized humanity. The understanding of social justice is written in fifth principle of Pancasila, Mahfud MD interprets it as:

"the distribution of resources is aimed to create social prosperity, especially for the lowest community groups or the weak socio-economic community. Besides, social justice also requires efforts to equalize resources so that weak community groups can be alleviated from poverty and so that socio-economic inequality in the midst of society can be reduced. Thus, the distribution of available resources can be called to be socially equitable if it can improve socio-economic life among community groups can be reduced."4

Furthermore, the meaning of fair and civilized as referred in the second principle of Pancasila, namely fair and civilized humanity, contains the following principles:

a recognition of human dignity and all its rights and obligations;

b fair treatment of fellow human beings, themselves, the environment and God;

c human beings as civilized or cultured creatures who have, created, willed, and believed. ${ }^{5}$

In the second precept also contained the principle of humanity or internationalism, and as the embodiment of the elements of human nature, body and soul, sense, will and nature of individual, and social beings. Based on the just and civilized precepts of humanity, it can be concluded that the legal justice possessed by the Indonesian people is justice that humanizes humans. Justice in second principle can be called as dignified justice. Dignified justice places human beings as creatures of God whose rights are guaranteed. ${ }^{6}$

From the discussion above, legal protection for the growth of children born from marriage can be through harmonization or unification of children's rights as developed by The Convention on The Right of The Child. But ideally also must pay attention to the values of justice that grow to develop as the values of the nation, or the Indonesian Volkgeist sourced from Pancasila.

\section{Conclusion}

From the results of the discussion, it can be concluded that the divorce case, whatever the reason, it is a disaster for the child, because the child will no longer be able to enjoy the love of both parents. For children who are born, the divorce of their parents is something that will ruin their lives and will adversely affect their growth and development. In this condition, the State must be present to establish legislation relating to the protection of children's rights. Because basically children's rights are basic rights that must be protected by the State. As a form of efforts to protect the law of children's rights, by ratifying The Convention on The Right of The Child

\footnotetext{
${ }^{1}$ Ibid.

${ }^{2}$ LM. Gandhi, Harmonization of Law Legal Harmonization Towards Responsive Law, Speech in Inaugural ceremony Professor in Universitas Indonesia, Jakarta, 1995, p.24

${ }^{3}$ Prasetyo Teguh, Dignified Justice The Perspective of Legal Theory, 1st Publication, Nusa Media, Bandung, 2015, p.40

${ }^{4}$ Mahfud, MD, Moh., Debate on Constitutional Law Post Constitutional Amendment Rajawali Pers, Jakarta, 2010,p.10-11.

${ }^{5}$ Prasetyo, Teguh, Law and Legal System Based on Pancasila, 1st Publication, Media Perkasa, Yogyakarta, 2013 , p.64.

${ }^{6}$ Teguh Prasetya, Op.cit., p.109.
} 
according to the Indonesia government based on UU of Indonesia Republic No. 10 of 2012 about Children Convention, then Indonesia should harmonize the laws relating to the protection of children's rights. Children's legislation must accommodate 4 (four) children's right as survival right, protection right, development rights, and participation rights. But ideally also must pay attention to the values of justice that grow to develop as the values of the nation, or the Indonesian Volkgeist sourced from Pancasila.

\section{REFERENCES}

Darwan Prinst, 1997, Indonesia Child Law, Citra Aditya Bakti, Bandung.

Huala Adolf, 2005, International Trade Law, Raja Grafindo Persada, Jakarta.

Jhon Griffiths, 2005, Understanding Law, A Conceptual Description in Pluralism Law: An Interdisciplinary Approach, translated by Andri Akbar et al. Huma, Jakarta.

LM. Gandhi, 1995, Harmonization of Law Legal Harmonization Towards Responsive Law, Speech in Inaugural ceremony Professor in Universitas Indonesia, Jakarta.

Lawrence M. Friedman, 2009, A Legal Sistem A Social Science Perspective translated by M. Khozim, Nusa Media, Bandung.

Mahfud, MD, Moh., 2010, Debate on Constitutional Law Post Constitutional Amendment Rajawali Pers, Jakarta. Philipus M. Hadjon, 1997, Legal Protection for Indonesian People. PT. Bina Ilmu, Surabaya.

Prasetyo, Teguh, 2013, Law and Legal System Based on Pancasila, 1st Publication, Media Perkasa, Yogyakarta.

Prasetyo Teguh, 2015, Dignified Justice The Perspective of Legal Theory, 1st Publication, Nusa Media, Bandung

Salim, Erlies Septiana Nurbadi, 2017, The Application of Legal Theory in Research of Thesis and Dissertation, 5th Publication, Rajawali Press, Depok.

Satria Effendi, 2004, Problem of the Law of Contemporary Islamic Family, Kencana, Jakarta.

Wibowo, Basuki Rekso, 2019, The Reformation of Indonesi Legal Based on Pancasila, Scientific Oration of Bachelor Graduation Program, Wijaya Putra University, 9 November.

Herzein Inlandsch Reglement atau HIR.

The Constitution Number 1 of 1974, about Marriages

The Constitution Number 50 of 2009 about The Second Change of The Constitution Number 7 of 1989 about The Religious Court.

The Constitution of Indonesia Republic Number 10 of 2012 about Children Convention.

The Constitution Number 35 of 2014 about The Change of The Constitution Number 23 of 2002 about Children's Protection

Presidential Instruction Number 1 of 1997 about The Compilation of Islamic Law. 